\title{
UJI METODE CERAMAH DAN TEORI BELAJAR KONTRUKTIVISME UNTUK CARA BELAJAR SISWA MENENGAH PERTAMA NEGERI 2 ARJASA
}

\author{
Dary Farhan Hafizh ${ }^{1 *}$ \\ 1) Mahasiswa Program Studi Pendidikan IPA, FKIP Universitas Jember \\ E-mail : daryfarhan7@gmail.com
}

\begin{abstract}
This study descriptively aims to determine the tendency of learning achievement, using constructivism learning models compared to lecture learning models. Data retrieval is done by observing, giving questionnaires and interviews with the subjects of students from schools of junior high school 2 Arjasa. Descriptive research results show that learning using the lecture learning method provides more understanding to students when compared to the constructivism learning model.
\end{abstract}

Keyword: study; Observation; learning

\section{PENDAhuluan}

Pengetahuan memiliki peran penting dalam peradaban manusia. Pengetahuan yang dikelola, upaya pencarian, pengembangan dan penyebarannya ke seluruh sendi organisasi sangat penting dari sekedar modal fisik yang dimiliki (Taufik, 2010). Berbagai perubahan yang terjadi diberbagai lini kehidupan di era pengetahuan (knowledge era), terutama perkembangan teknologi, informasi dan komunikasi dianggap penting oleh dunia pendidikan. Salah satu aspek yang diubah dan diperbaiki adalah proses belajar mengajar. Institusi pendidikan menyadari perlunya pendekatan pembelajaran yang berpusat pada peserta didik (learner centered) (Taufik, 2010).

Pembelajaran pada hakikatnya adalah suatu proses untuk memperoleh perubahan tingkah laku, berupa penambahan pengetahuan hasil interaksi dengan lingkungan sekitar. Selama ini proses pembelajaran yang ditemui di sekolah masih menggunakan model pembelajaran yang berpusat pada guru. Proses pembelajaran tersebut hanya menekankan pencapaian secara kognitif, dan kurang mengembangkan kemampuan belajar dan kemampuan individu dari masing masing siswa. Hal ini menyebabkan siswa mengalami kesulitan dalam menerima dan memahami konsep yang disampaikan oleh guru karena siswa hanya memperoleh materi pembelajaran secara abstrak dan menyebabkan nilai yang didapat tidak maksimal.

Seorang guru perlu memperhatikan konsep awal siswa sebelum pembelajaran. Jika tidak demikian, maka seorang pendidik tidak akan berhasil menanamkan konsep yang benar, bahkan dapat memunculkan sumber kesulitan belajar selanjutnya. Mengajar bukan hanya untuk meneruskan gagasan-gagasan pendidik pada siswa, melainkan sebagai proses mengubah konsepsi-konsepsi siswa yang sudah ada dan di mana mungkin konsepsi itu salah, dan jika ternyata benar maka pendidik harus membantu siswa dalam mengkonstruk konsepsi tersebut biar lebih matang.

Pembelajaran Konstruktivistik adalah membangunkan pengetahuan melalui pengalaman, interaksi social, dan dunia nyata. Pembelajaran Konstruktivistik adalah pembelajaran berpusat pada peserta didik, guru sebagai mediator, fasilitator, dan sumber belajar dalam pembelajaran (husamah, dkk, 2016).

Prinsip-prinsip dasar konstruktivisme yakni peserta didik membangun interpretasi dirinya terhadap dunia nyata melalui pengalaman-pengalaman baru dan interaksi social, Pengetahuan yang telah melekat dapat dipergunakan (memahami kenyataan), fleksibel menggunakan pengetahuan, mempercayai berbagai cara (beragam perspektif) untuk menstruktur dunia dan 
mengisinya dan mempercayai individu dapat memaknai kehidupan di dunia secara bebas (Suryono, 2013).

Metode adalah cara yang digunakan untuk mengimplementasikan rencana yang sudah disusun dalam kegiatan nyata agar tujuan yang telah disusun tercapai secara optimal. Ceramah merupakan salah satu metode mengajar yang paling banyak digunakan dalam proses belajar mengajar. Metode ceramah ini dilakukan dengan cara menyampaikan materi pelajaran kepada peserta didik secara langsung atau dengan cara lisan. Penggunaan metode ini sifatnya sangat praktis dan efisien bagi pemberian pengajaran yang bahannya banyak dan mempunyai banyak peserta didik. Metode ceramah merupakan cara mengajar yang paling tradisional dan telah lama dijalankan dalam sejarah pendidikan, oleh karena itu metode ini boleh dikatakan sebagai metode pengajaran tradisional karena sejak dulu metode ini digunakan sebagai alat komunikasi guru dalam menyampaikan materi pelajaran.

Metode ceramah dapat diartikan sebagai cara menyajikan pelajaran melalui penuturan secara lisan atau penjelasan langsung kepada sekelompok siswa (Sanjaya, 2009).

Tahapan cara melakukan metode ceramah yaitu:

1. Melakukan pendahuluan sebelum bahan baru diberikan dengan cara sebagai berikut:

a. Menjelaskan tujuan lebih dulu kepada peserta didik dengan maksud agar peserta didik mengetahui arah kegiatannya dalam belajar, bahkan tujuan itu dapat membangkitkan motivasi belajar jika bertalian dengan kebutuhan mereka.

b. Setelah itu baru dikemukakan pokok-pokok materi yang akan dibahas. Hal ini dimaksudkan agar peserta didik melihat luasnya bahan pelajaran yang akan dipelajarinya.

c. Memancing pengalaman peserta didik yang cocok dengan materi yang akan dipelajarinya. Caranya ialah dengan pertanyaanpertanyaan yang menarik perhatian mereka.

2. Menyajikan bahan baru dengan memperhatikan faktor-faktor sebagai berikut:

a. Perhatian peserta didik dari awal sampai akhir pelajaran harus tetap terpelihara. Semangat mengajar memberi bantuan sepenuhnya dalam memelihara perhatian peserta didik kepada pelajarannya.

b. Menyajikan pelajaran secara sistematis, tidak berbelit-belit dan tidak meloncat-loncat.

c. Kegiatan belajar mengajar diciptakan secara variatif, jangan membiarkan peserta didik hanya duduk dan mendengarkan, tetapi berilah kesempatan untuk berpikir dan berbuat. Misalnya pelatihan mengerjakan tugas, mengajukan pertanyaan, berdiskusi, atau melihat peragaan.

d. Memberi ulangan pelajaran kepada response, jawaban yang salah dan benar perlu ditanggapi sebaikbaiknya.

e. Membangkitkan motivasi belajar secara terus menerus selama perjalanan berlangsung. Motivasi belajar akan selalu tumbuh jika sesuatu belajar menyenangkan.

f. Menggunakan media pelajaran yang variatif, yang sesuai dengan tujuan pelajaran.

3. Menutup pelajaran pada akhir pelajaran. Kegiatan perlu diperhatikan pada penutupan itu adalah sebagai berikut:

a. Mengambil kesimpulan dari semua pelajaran yang telah diberikan, dilakukan oleh peserta didik di bawah bimbingan guru.

b. Memberikan kesempatan pada peserta didik untuk menanggapi materi pelajaran yang telah diberikan terutama mengenai hubungan dengan pelajaran lain.

c. Melaksanakan penilaian secara komprehensif untuk mengukur perubahan tingkah laku. 


\section{METODE}

Penelitian ini menggunakan metode kualitatif yaitu prosedur penelitian yang menghasilkan data deskriptif berupa katakata tertulis atau lisan dari orang-orang dan perilaku yang dapat diamati.

Cara pengumpulan data yang digunakan pada penelitian ini dengan memperhatikan, pengisian angket dan mewawancarai subjek yang terdiri dari peserta didik dari SMP negeri 2 Arjasa. subjek dikumpulkan dalam satu ruangan lalu diberikan angket kepada subjek dan setelah selesai mengerjakan, dipilih beberapa peserta didik secara acak lalu subjek diwawancarai dengan pertanyaan sebagai berikut, apakah guru disekolah anda menjelaskan materi yang akan dipelajari terlebih dahulu, apakah setelah dijelaskan siswa ditunjuk untuk mengerjakan soal didepan, apakah guru membenarkan apa bila anda salah. Setelah dilakukan wawancara kepada subjek lalu diperhatikan saat subjek sedang melaksanakan kegiatan belajar mengajar. Angket yang kami berikan yaitu sebuah gagasan yang mendeskripsikan masing masing metode belajar tersebut.

\section{HASIL DAN PEMBAHASAN}

\section{Pendidikan masyarakat di daerah SMPN 2 Arjasa}

SMPN 2 Arjasa merupakan sebuah sekolah menengah pertama yang terletak jauh dari pusat kota, mayoritas penduduk disana menggunakan bahasa Madura sebagai bahasa sehari hari karena letaknya yang jauh dari pusat kota dan mata pencaharian penduduk setempat yaitu berkebun, seringkali masyarakat disana kurang memperhatikan pendidikan. Oleh sebab itu rata rata masyrakat di sekitar daerah disana dapat dibilang memiliki pendidikan yang cukup rendah.

Karena pendidikan yang masih rendah maka orang tua disana kurang memperhatikan anak anaknya dalam bidang pendidikan. Rata rata penduduk disana sudah berangkat bercocok tanam terlebih dahulu sebelum anak mereka berangkat sekolah. Hal ini mengakibatkan anak anak di SMPN 2 Arjasa kurang mendapat perhatian yang cukup dari orang tua mereka.

\section{Hasil pemberian angket}

Angket yang diberikan berupa kalimat yang mendekskripsikan beberapa kepribadian yang ada pada siswa. Tujuan pemberian angket yaitu untuk mempermudah siswa dalam menentukan model pembelajaran seperti apa yang paling disukai. Metode pemberian angket siswa dilakukan dengan cara diberikan angket, lalu di berikan waktu kurang lebih 30 menit untuk menjawab semua pertanyaan yang ada, jawaban yang benar diberikan tanda $(\checkmark)$. Bentuk angket yang diberikan pada penelitian ini seperti pada tabel 1

Tabel 1.Angket Metode Pembelajaran

\begin{tabular}{|c|c|c|c|}
\hline Pertanyaan & SS & $\mathrm{S}$ & TS \\
\hline $\begin{array}{l}\text { 1. Anda merasa lebih paham saat guru menjelaskan materi } \\
\text { secara langsung. }\end{array}$ & & & \\
\hline 2. Anda tidak mengantuk saat guru menjelaskan. & & & \\
\hline 3. Anda sering bertanya saat kegiatan pembelajaran. & & & \\
\hline 4. Anda jarang bertanya saat pembelajaran berlangsung. & & & \\
\hline $\begin{array}{l}\text { 5. Anda merasa lebih mengerti saat disuruh mengerjakan } \\
\text { soal didepan. }\end{array}$ & & & \\
\hline $\begin{array}{l}\text { 6. Biasanya guru disekolah menunjuk murid untuk maju } \\
\text { menjawab soal. }\end{array}$ & & & \\
\hline 7. Biasanya guru hanya menjelaskan lalu memberi tugas. & & & \\
\hline
\end{tabular}


8. Anda tidak merasa bosan saat disuruh untuk maju.

Keterangan :

SS : (sangat setuju)

$S$ : (setuju)

TS : (Tidak Setuju)

Hasil pemberian angket menunjukkan dari 25 murid yang menjawab semua jawaban lebih condong kearah

metode pembelajaran ceramah. Hasil dari pemberian angket tertera pada table 2 .

Tabel 2.Hasil Pemberian Angket

\begin{tabular}{|c|c|c|c|}
\hline Pertanyaan & $\mathrm{SS}$ & $\mathrm{S}$ & TS \\
\hline $\begin{array}{l}\text { 1. Anda merasa lebih paham saat guru menjelaskan materi } \\
\text { secara langsung. }\end{array}$ & 18 & 7 & 0 \\
\hline 2. Anda tidak mengantuk saat guru menjelaskan. & 0 & 14 & 11 \\
\hline 3. Anda sering bertanya saat kegiatan pembelajaran. & 0 & 6 & 19 \\
\hline 4. Anda jarang bertanya saat pembelajaran berlangsung. & 21 & 1 & 3 \\
\hline $\begin{array}{l}\text { 5. Anda merasa lebih mengerti saat disuruh mengerjakan } \\
\text { soal didepan. }\end{array}$ & 0 & 1 & 24 \\
\hline $\begin{array}{l}\text { 6. Biasanya guru disekolah menunjuk murid untuk maju } \\
\text { menjawab soal. }\end{array}$ & 0 & 17 & 8 \\
\hline 7. Biasanya guru hanya menjelaskan lalu memberi tugas. & 19 & 4 & 1 \\
\hline 8. Anda tidak merasa bosan saat disuruh untuk maju. & 1 & 1 & 23 \\
\hline
\end{tabular}

Table 2 merupakan hasil dari pengisian angket yang telah direkap. Pada poin nomor 1,18 orang siswa memilih sangat setuju dan 7 orang lainnya setuju itu artimya $100 \%$ siswa kelas 9B merasa lebih paham ketika guru menjelaskan materi secara langsung.

Pada poin yang kedua 14 orang siswa memilih setuju dan 11 lainya memilih tidak setuju, karena kuota setuju melebihi 50\% maka dapat dikatakan sebagian besar siswa/siswi SMPN 2 Arjasa menikmati pembelajaran yang tengah berlangsung.

Untuk poin ketiga yaitu 19 siswa memilih tidak setuju itu artinya hampir seluruh kelas tersebut tidak bertanya saat pembelajaran berlangsung. Dengan demikian setelah melihat dari poin 1 sampai dengan poin 8 jawaban yang dipilih siswa kelas 9B lebih menyukai metode ceramah.

\section{Hasil wawancara}

Wawancara dilakukan dengan memilih 4 subjek secara acak, Subjek dipilih dari kelas 9b SMPN 2 Arjasa. Wawancara yang dilakukan dengan sesi tanya jawab, Tanya jawab dilakukan secara bergantian antra siswa yang telah dikumpulkan ( dipilih ). Diberikan sebuah pertanyaan yang merupakan inti dari penelitian ini yaitu apakah kamu lebih suka belajar dengan mengerjakan langsung setelah mendengar jawaban dari guru. Keempat subjek kompak untuk menjawab tidak. Alasan mereka menjawab tidak karena mereka tidak terlalu mementingkan pendidikan, mereka menjelaskan bahwasannya mereka lebih tertarik untuk bekerja membantu orang tua mereka dikebun.

Subjek nomor 1 mengatakan bahwasannya dia tidak menyukai ditunjuk secara langsung oleh guru karena membuat dirinya takut, kemudian subjek juga menjelaskan bahwasannya diajar dengan langsung dijelaskan di papan tulis dan mendengarkan lebih disukainya dengan alasan lebih materi lebih cepat selesai dan siwa cepat dipuangkan.

Persekolahan di desa tidak sama dengan persekolahan di perkotaan. Didesa banyak murid murid yang ikut membantu 
orang tuanya dan prilakunyapun tidak sama dengan prilaku siswa di kota. Jika dikota rata rata siswa menghormati guru, di daerah wawancara dan siswa yang diwawancarai menjawab pertanyaan semau mereka dan sesenang mereka tanpa mengetahui maksud dari pertanyaannya meskipun ada sebagian siswa yang dapat dikatakan berprestasi dan hormat kepada guru.

\section{Hasil Pemerhatian}

Setelah dilakukan observasi dan diamati selama kurang lebih 1 minggu dapat terlihat bahwasannya siswa di SMPN 2 Arjasa sebagian besar siswa disana kurang memiliki semangat untuk belajar, pemikiran mereka berfdokus untuk mencari pekerjaan dan mendapatkan uang.

Dari hasil pemberian angket, wawancara, dan pemerhatian dapat dikatakan metode pembelajaran yang paling cocok bagi murid 9B SMPN 2 Arjasa adalah metode pembelajaran ceramah. Itu karena watak dari murid SMPN 2 Arjasa yang lebih mementingkan untuk mencari uang, sebelumnya juga pernah dilakukan model pembelajaran kontruktivisme namun pada saat pembelajaran kelas menjadi kurang kondusif dan siswa sulit untuk memahami materi yang telah diberikan.

Sebenarnya hubungan metode pembelajaran yang digunakan pada saat pembelajaran juga merupakan ciri dari cara hidup masyrakat disana, minimnya pendidikan yang dimiliki orang tua siswa dan siswi disana mengakibatkan kurang terpantaunya kegiatan pembelajaran yang akan dilakukan disekolah. Karena pendidikan yang paling mengubah cara berpikir serta prilaku sesesorang pertama kali berada dalam lingkup keluarga bukan hanya disekolah tetapi di lingkungan keluarga semestinya memberi pengaruh yang sangat besar bagi seseorang. Orangtua pada umumnya seharusnya memperhatikan apa saja perlengkapan sekolah dari putra dan putrinya, bukan hanya itu peran orang tua dalam membentuk karakter anak mereka sangat besar.

Kenyataannya orang tua siswa disana malah kurang mementingkan pendidikan pada anak mereka, mereka lebih suka anak desa siswa masih kurang menghormati guru mereka hal ini terbukti saat dilakukan

mereka untuk ikut ke sawah dan mencari rumput untuk membantu meringankan beban pekerjaan mereka. Hal tersebut berakibat kepada anak meraka, siswa siswi disana kurang memiliki semangat dalam melakukan kegiatan belajar pembelajaran. Sehingga metode yang paling cocok digunakan pada kelas yaitu metode ceramah.

Metode ceramah yaitu cara menjelaskan dimana guru sebagai pusat pembelajaran. Namun metode ini memang memiliki kelebihan namun juga memiliki kelemahan. Kelebihannya guru dapat mengeksplore semua pengetahuan yang mereka miliki dengan leluarsa sehingga siswa dan siswa yang diajar mendapatkan banyak informasi baru, namun kekurang metode ini yaitu siswa cenderung kurang aktif dan kurang mendapat pengalaman langsung.

\section{KESIMPULAN}

Siswa di SMPN 2 Arjasa lebih cocok untuk menggunakan metode pembelajaran ceramah. Alasannya karena watak dan cara berpikir siswa dan siswi disana yang kurang memiliki semangat dalam bidang pendidikan, apabila dipaksakan menggunakan metode pembelajaran kontruktivisme maka siswa disana malah kebingungan dan tidak paham dengan materi yang dipelajari, factor lainnya juga karena kurangnya perhatian dari orang tua.

\section{SARAN}

Untuk para siswa lebih ditingkatkan lagi semangat dalam belajar, lebih menghargai apa yang diucapkan oleh guru. Dan untuk orang tua siswa agar lebih memperhatikan prilaku dan kegiatan belajar putra atau putrinya.

\section{DAFTAR PUSTAKA}

Gulo, W. 2008. Strategi Belajar Mengajar. Grasindo.

Husamah, dkk. 2016. Belajar dan Pembelajaran. Malang : UMM Press. 
N. K, Roestiyah. 2001. Strategi Belajar Mengajar. Jakarta: Rineka Cipta. hal 137.

Nuryani, Dwi, dkk. 2015. Latar belakang dan dampak perkawinan endogamy di daerah sdigde kabupaten jeparah. Semarang: ITS.

Soetopo, Hendyat. 2005. Pendidikan dan Pembelajaran. Malang: UMM Press.

Suryono, dkk. 2013. Teknik Belajar Mengajar Dalam CBSA. Jakarta: Rineka Cipta.
Suryosubroto, B. 2002. Proses Belajar Mengajar di Sekolah. Jakarta: Rineka Cipta

Taufik A. 2010. Inovasi Pendidikan Melalui Problem Based Learning. Jakarta: Kencana Prenada Media Group.

Yamin, Martinis. 2013. Paradigma Baru Pembelajaran. Jakarta: hal 24. 